Check for updates

Cite this: RSC Adv., 2017, 7, 25765

Received 7th April 2017

Accepted 30th April 2017

DOI: $10.1039 / c 7 r a 03948 d$

rsc.li/rsc-advances

\section{New triterpene saponins from the aerial parts of Androsace umbellata $\dagger$}

\author{
Zhi-Qi Yin, (D)*a Lei Wang, ${ }^{\text {ab }}$ Cheng-Hua Li, ${ }^{a}$ Dong-Mei Zhang, ${ }^{b}$ Wei Zhang, ${ }^{\text {ab }}$ \\ Ying Wang, ${ }^{\mathrm{b}}$ Ming Zhao, ${ }^{\mathrm{c}}$ Chun-Tao Che ${ }^{\mathrm{c}}$ and Wen-Cai Ye (DD ${ }^{\mathrm{b}}$
}

Six new oleanane-type triterpene saponins, androsides A-F (1-6), along with two known compounds (7-8), were isolated from the aerial parts of Androsace umbellata. The structures were determined on the basis of spectroscopic data and acid hydrolysis. The aglycones in 1-5 are novel structures. Cytotoxicity assays using HepG2, HepG2/ADM, MCF-7, MCF-7/ADR and MDA-MB-231 cell lines indicated that 7 and 8 , both bearing a 13ß,28-epoxy group, were active. Compound 8 was shown to induce apoptosis in the HepG2/ADM cells.

\section{Introduction}

Plants of the genus Androsace (Primulaceae) include 120 species, of which about 73 species are distributed mainly in China. ${ }^{1}$ Pharmacological studies have demonstrated that Androsace plants possess anti-tumor, anti-inflammatory and anti-virus properties, ${ }^{2}$ and phytochemical investigations revealed triterpene saponins and flavonoids as major ingredients. ${ }^{3}$ Androsace umbellata is distributed in Asia, especially China, Japan and India. The whole plant of $A$. umbellata has been used in Chinese folk medicine for the treatment of laryngopharyngitis, tonsillitis and hydropsia. ${ }^{4}$ Recently, triterpene saponins isolated from $A$. umbellata were found to show cytotoxic activity against human tumor cell lines. ${ }^{5}$ Saxifragifolin D could inhibit breast cancer cell growth and induce interplay between apoptosis and autophagy. ${ }^{6}$

In the search for bioactive constituents from $A$. umbellata, we have reported several triterpene and phenolic glycosides from this plant. ${ }^{7,8}$ Continuing phytochemical studies now led to the isolation of six new triterpenesaponins, androsides A-F (1-6) (Fig. 1), along with two known saponins (7-8).

\section{Results and discussion}

\section{Structural elucidation}

An ethanol extract of the aerial parts of A. umbellata was subjected to repeated column chromatography over silica gel, ODS

${ }^{a}$ Department of Natural Medicinal Chemistry \& State Key Laboratory of Natural Medicines, China Pharmaceutical University, Nanjing 210009, P.R. China. E-mail: cpu-yzq@cpu.edu.cn; Tel: +86-025-86185371

${ }^{b}$ Institute of Traditional Chinese Medicine and Natural Products, College of Pharmacy, Jinan University, Guangzhou 510632, P.R. China

${ }^{c}$ Department of Medicinal Chemistry and Pharmacognosy, WHO Collaborating Center for Tradition Medicine, College of Pharmacy, University of Illinois at Chicago, Chicago, IL 60612, USA

$\dagger$ Electronic supplementary information (ESI) available: Spectroscopic data and other relevant information for compounds 1-8. See DOI: 10.1039/c7ra03948d silica gel and Sephadex LH-20 to afford six new triterpene saponins, androsides A-F (1-6), along with saxifragifolin B (7) and saxifragifolin A (8). ${ }^{9}$

Androside A (1) was obtained as an amorphous powder. Positive results from both Liebermann-Burchard and Molisch reactions indicated a triterpene glycoside structure. The molecular formula of 1 was determined to be $\mathrm{C}_{36} \mathrm{H}_{56} \mathrm{O}_{11}$ by the quasi-molecular ion $[\mathrm{M}+\mathrm{Na}]^{+}$at $\mathrm{m} / \mathrm{z} 687.3709$ (calcd for $\mathrm{C}_{36} \mathrm{H}_{56} \mathrm{O}_{11} \mathrm{Na}$ : 687.3714) in HR-ESI-MS. The IR spectrum showed characteristic absorptions for hydroxyl $\left(3442 \mathrm{~cm}^{-1}\right)$, carboxyl $\left(1726 \mathrm{~cm}^{-1}\right)$ and olefinic bonds $\left(1646 \mathrm{~cm}^{-1}\right)$. Acid hydrolysis of 1 afforded D-glucose, which were detected by derivatization and HPLC analysis.

The ${ }^{1} \mathrm{H}$ NMR spectrum of $\mathbf{1}$ (Table 1 ) displayed six tertiary methyl signals at $\delta_{\mathrm{H}} 0.85,0.85,0.86,1.29,1.38$, and 1.80 (each $3 \mathrm{H}, \mathrm{s})$, an olefinic proton at $\delta_{\mathrm{H}} 5.62(1 \mathrm{H}$, br s), as well as an anomeric protons at $\delta_{\mathrm{H}} 6.46(1 \mathrm{H}, \mathrm{d}, J=8.0 \mathrm{~Hz})$. The ${ }^{13} \mathrm{C} \mathrm{NMR}$ and DEPT spectra (Table 1) exhibited 36 carbon signals, 30 of which could be attributed to the aglycone. The ${ }^{13} \mathrm{C}$ NMR resonances at $\delta_{\mathrm{C}} 122.5$ and 144.7 further suggested the presence of a $\Delta^{12,13}$ double bond on an oleanane skeleton. ${ }^{10}$ When the ${ }^{13} \mathrm{C}$ NMR spectrum of $\mathbf{1}$ was compared with that of ardisicrenoside

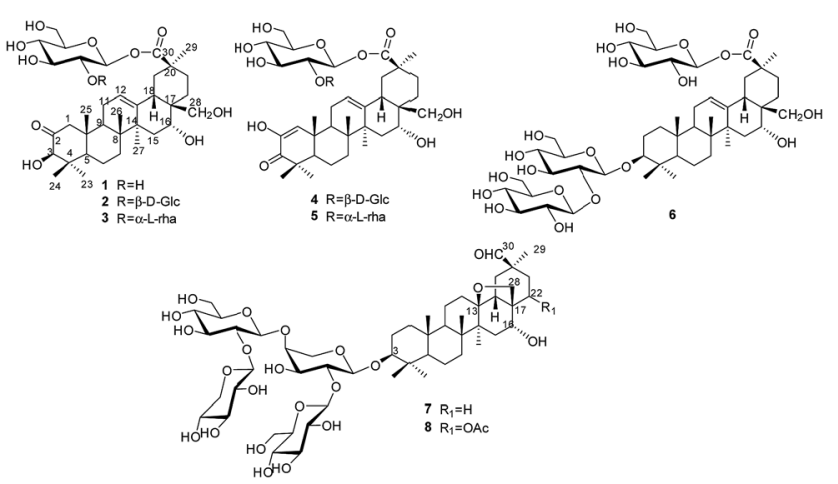

Fig. 1 Chemical structures of $1-8$ 
Table $1{ }^{1} \mathrm{H}$ NMR and ${ }^{13} \mathrm{C}$ NMR spectroscopic data of compounds 1,2 and $4\left(\delta \text { in ppm, } \mathrm{J} \text { in } \mathrm{Hz}, \mathrm{C}_{5} \mathrm{D}_{5} \mathrm{~N}\right)^{a, b}$

\begin{tabular}{|c|c|c|c|c|c|c|}
\hline \multirow[b]{2}{*}{ Position } & \multicolumn{2}{|l|}{1} & \multicolumn{2}{|l|}{2} & \multicolumn{2}{|l|}{4} \\
\hline & $\delta_{\mathrm{H}}$ & $\delta_{\mathrm{C}}$ & $\delta_{\mathrm{H}}$ & $\delta_{\mathrm{C}}$ & $\delta_{\mathrm{H}}$ & $\delta_{\mathrm{C}}$ \\
\hline 1 & $2.23, \mathrm{br} \mathrm{d}(12.0) 2.48, \mathrm{~m}$ & $53.8, \mathrm{CH}_{2}$ & $2.21, \mathrm{~d}(12.5) 2.47, \mathrm{~m}$ & $53.8, \mathrm{CH}_{2}$ & $6.52, \mathrm{~s}$ & $129.5, \mathrm{CH}$ \\
\hline 2 & - & 211.1, C & - & 211.1, C & - & $146.3, \mathrm{C}$ \\
\hline 3 & $4.19, \mathrm{~s}$ & $83.3, \mathrm{CH}$ & $4.17, \mathrm{~s}$ & $83.3, \mathrm{CH}$ & - & 201.1, C \\
\hline 4 & - & $45.7, \mathrm{C}$ & - & $45.7, \mathrm{C}$ & - & $44.6, \mathrm{C}$ \\
\hline 5 & 1.55, br d (10.8) & $54.8, \mathrm{CH}$ & 1.56, br d (11.0) & $54.8, \mathrm{CH}$ & 1.65, br d $(9.2)$ & $54.1, \mathrm{CH}$ \\
\hline 6 & 1.36.1.54, m & $18.9, \mathrm{CH}_{2}$ & $1.36,1.56, \mathrm{~m}$ & $18.9, \mathrm{CH}_{2}$ & - & $19.1, \mathrm{CH}_{2}$ \\
\hline 7 & $1.35,1.68, \mathrm{~m}$ & $32.8, \mathrm{CH}_{2}$ & $1.34,1.69, \mathrm{~m}$ & $32.8, \mathrm{CH}_{2}$ & $1.34,1.68, \mathrm{~m}$ & $33.0, \mathrm{CH}_{2}$ \\
\hline 8 & - & $40.3, \mathrm{C}$ & - & $40.3, \mathrm{C}$ & - & $40.6, \mathrm{C}$ \\
\hline 9 & $2.02, \mathrm{~m}$ & $46.7, \mathrm{CH}$ & $2.02, \mathrm{~m}$ & $46.7, \mathrm{CH}$ & $2.04, \mathrm{~m}$ & $42.8, \mathrm{CH}$ \\
\hline 10 & - & $43.2, \mathrm{C}$ & - & $43.6, \mathrm{C}$ & - & $38.4, \mathrm{C}$ \\
\hline 11 & $1.70,2.01, \mathrm{~m}$ & 23.6, $\mathrm{CH}_{2}$ & $1.76, \mathrm{~m}$ & 23.7, $\mathrm{CH}_{2}$ & $1.90,2.05, \mathrm{~m}$ & $23.8, \mathrm{CH}_{2}$ \\
\hline 12 & $5.62, \mathrm{~s}$ & $122.5, \mathrm{CH}$ & 5.79, br s & $122.4, \mathrm{CH}$ & 5.74, br s & $122.6, \mathrm{CH}$ \\
\hline 13 & - & 144.7, C & - & $144.8, \mathrm{C}$ & - & $145.0, \mathrm{C}$ \\
\hline 14 & - & $41.9, \mathrm{C}$ & - & $42.0, \mathrm{C}$ & - & $42.2, \mathrm{C}$ \\
\hline 15 & $\begin{array}{l}1.63, \mathrm{~m} 2.20 \\
\text { br d }(13.4)\end{array}$ & $34.9, \mathrm{CH}_{2}$ & $\begin{array}{l}\text { 1.63, m 2.19, } \\
\text { dd (6.8.10.8) }\end{array}$ & $34.8, \mathrm{CH}_{2}$ & $\begin{array}{l}1.60, \mathrm{~m} 2.21 \\
\text { br d (11.1) }\end{array}$ & $34.8, \mathrm{CH}_{2}$ \\
\hline 16 & $4.66, \mathrm{~s}$ & $74.0, \mathrm{CH}$ & 4.72, br s & $74.0, \mathrm{CH}$ & 4.72, br s & 74.1, CH \\
\hline 17 & - & $40.4, \mathrm{C}$ & - & $40.4, \mathrm{C}$ & - & $40.6, \mathrm{C}$ \\
\hline 18 & $2.78, \mathrm{~m}$ & $43.4, \mathrm{CH}$ & $2.65, \mathrm{~m}$ & $43.4, \mathrm{CH}$ & 2.86, dd $(10.8,11.6)$ & $43.8, \mathrm{CH}$ \\
\hline 19 & $\begin{array}{l}2.35, \text { br d (12.7) } \\
2.85, \mathrm{~d}(12.2)\end{array}$ & $44.7, \mathrm{CH}_{2}$ & $2.41, \mathrm{~m} \mathrm{2.88, \textrm {t } ( 1 3 . 0 )}$ & $44.2, \mathrm{CH}_{2}$ & $2.42,2.88, \mathrm{~m}$ & 44.1, $\mathrm{CH}_{2}$ \\
\hline 20 & - & $44.6, \mathrm{C}$ & - & $44.6, \mathrm{C}$ & - & $44.6, \mathrm{C}$ \\
\hline 21 & $2.48, \mathrm{~m}$ & $33.6, \mathrm{CH}_{2}$ & $2.53, \mathrm{~m}$ & $33.4, \mathrm{CH}_{2}$ & $2.50, \mathrm{~m}$ & $33.9, \mathrm{CH}_{2}$ \\
\hline 22 & $\begin{array}{l}2.35, \text { br d }(12.7) \\
2.57, \mathrm{~m}\end{array}$ & $31.8, \mathrm{CH}_{2}$ & $2.46, \mathrm{~m}$ & $31.8, \mathrm{CH}_{2}$ & $2.43, \mathrm{~m}$ & $31.8, \mathrm{CH}_{2}$ \\
\hline 23 & $1.29, \mathrm{~s}$ & $29.4, \mathrm{CH}_{3}$ & $1.28, \mathrm{~s}$ & $29.4, \mathrm{CH}_{3}$ & $1.19, \mathrm{~s}$ & $27.8, \mathrm{CH}_{3}$ \\
\hline 24 & $0.85, \mathrm{~s}$ & $17.3, \mathrm{CH}_{3}$ & $0.84, \mathrm{~s}$ & $17.2, \mathrm{CH}_{3}$ & $1.11, \mathrm{~s}$ & $20.2, \mathrm{CH}_{3}$ \\
\hline 25 & $0.85, \mathrm{~s}$ & $16.6, \mathrm{CH}_{3}$ & $0.85, \mathrm{~s}$ & $16.6, \mathrm{CH}_{3}$ & $1.10, \mathrm{~s}$ & $22.1, \mathrm{CH}_{3}$ \\
\hline 26 & $0.86, \mathrm{~s}$ & $16.5, \mathrm{CH}_{3}$ & $0.85, \mathrm{~s}$ & $16.5, \mathrm{CH}_{3}$ & $0.92, \mathrm{~s}$ & $17.4, \mathrm{CH}_{3}$ \\
\hline 27 & $1.80, \mathrm{~s}$ & $27.3, \mathrm{CH}_{3}$ & $1.80, \mathrm{~s}$ & $27.2, \mathrm{CH}_{3}$ & $1.76, \mathrm{~s}$ & $27.1, \mathrm{CH}_{3}$ \\
\hline 28 & $3.65, \mathrm{dd}(8.2,2.0)$ & $70.0, \mathrm{CH}_{2}$ & $3.52,3.68$, dd $(10.8)$ & $70.1, \mathrm{CH}_{2}$ & $3.53,3.70$, dd $(9.5)$ & $70.1, \mathrm{CH}_{2}$ \\
\hline 29 & $1.38, \mathrm{~s}$ & 28.6, $\mathrm{CH}_{3}$ & $1.48 \mathrm{~s}$ & $28.5, \mathrm{CH}_{3}$ & $1.49, \mathrm{~s}$ & $28.4, \mathrm{CH}_{3}$ \\
\hline 30 & - & 177.1, C & - & 177.1, C & - & $177.2, \mathrm{C}$ \\
\hline Glc1' $^{\prime}$ & $6.46, \mathrm{~d}(8.0)$ & $95.9, \mathrm{CH}$ & $6.38, \mathrm{~d}(8.0)$ & 93.7, CH & $6.39, \mathrm{~d}(8.0)$ & $93.7, \mathrm{CH}$ \\
\hline $2^{\prime}$ & $4.21, \mathrm{t}(8.1)$ & 74.5, CH & $4.46, \mathrm{~d}(8.7)$ & $81.3, \mathrm{CH}$ & $4.46, \mathrm{t}(8.5)$ & $81.3, \mathrm{CH}$ \\
\hline $3^{\prime}$ & $4.28, \mathrm{t}(8.1)$ & 78.6, CH & $4.20, \mathrm{t}(8.9)$ & $78.5, \mathrm{CH}$ & $4.20, \mathrm{t}(8.9)$ & $79.7, \mathrm{CH}$ \\
\hline $4^{\prime}$ & 4.30, br d (9.1) & $71.3, \mathrm{CH}$ & $4.29, \mathrm{~m}$ & $71.0, \mathrm{CH}$ & $4.29, \mathrm{t}(9.0)$ & $71.0, \mathrm{CH}$ \\
\hline $5^{\prime}$ & $4.01, \mathrm{~m}$ & $79.3, \mathrm{CH}$ & $3.94, \mathrm{~m}$ & $79.0, \mathrm{CH}$ & $3.94, \mathrm{~m}$ & $79.0, \mathrm{CH}$ \\
\hline $6^{\prime}$ & $\begin{array}{l}4.34, \text { dd }(4.5,11.6) \\
4.42, \mathrm{~d}(9.8)\end{array}$ & $62.4, \mathrm{CH}_{2}$ & $\begin{array}{l}4.30, \mathrm{dd}(5.3,9.5) \\
4.41, \mathrm{dd}(4.5 .11 .6)\end{array}$ & $62.3, \mathrm{CH}_{2}$ & $\begin{array}{l}4.30, \text { br d }(9.0) \\
4.41, \text { br d }(10.8)\end{array}$ & $62.3, \mathrm{CH}_{2}$ \\
\hline Glc1" & & & $5.53 \mathrm{~d}(8.0)$ & 105.6, CH & $5.55 \mathrm{~d}(8.0)$ & $105.6, \mathrm{CH}$ \\
\hline $2^{\prime \prime}$ & & & $4.73, \mathrm{br} \mathrm{s}$ & 76.4, CH & $4.72, \mathrm{br} \mathrm{s}$ & $76.4, \mathrm{CH}$ \\
\hline $3^{\prime \prime}$ & & & $4.33, \mathrm{t}(8.7)$ & $78.2, \mathrm{CH}$ & $4.33, \mathrm{t}(9.0)$ & $78.2, \mathrm{CH}$ \\
\hline $4^{\prime \prime}$ & & & $4.32, \mathrm{t}(8.7)$ & $71.4, \mathrm{CH}$ & $4.32, \mathrm{t}(9.0)$ & $71.4, \mathrm{CH}$ \\
\hline $5^{\prime \prime}$ & & & $3.89, \mathrm{~m}$ & $78.4, \mathrm{CH}$ & $3.89, \mathrm{~m}$ & $78.4, \mathrm{CH}$ \\
\hline $6^{\prime \prime}$ & & & $4.30,4.41, \mathrm{~m}$ & 62.6, $\mathrm{CH}_{2}$ & $4.30,4.41, \mathrm{~m}$ & $62.6, \mathrm{CH}_{2}$ \\
\hline
\end{tabular}

${ }^{a}{ }^{1} \mathrm{H}$ NMR Spectrum was measured at $500 \mathrm{MHz} ;{ }^{13} \mathrm{C}$ NMR Spectrum was measured at $125 \mathrm{MHz} .{ }^{b}$ Overlapping signals were reported without designating multiplicity.

$\mathrm{C}^{11}$ signals for carbons of rings $\mathrm{B}-\mathrm{E}$ were almost identical (Table 1). On the other hand, a ketone carbon signal resonating at $\delta_{\mathrm{C}} 211.1$ was observed, which was assigned to $\mathrm{C}-2$ by the HMBC correlations between $\delta_{\mathrm{C}} 211.1$ and $\delta_{\mathrm{H}} 2.23$ and $2.48(\mathrm{H}-1)$, as well as between $\delta_{\mathrm{C}} 211.1$ and $\delta_{\mathrm{H}} 4.19(\mathrm{H}-3)$ (Fig. 2). Thus, the aglycone of 1 was determined to be 2-oxo-3 $\beta, 16 \alpha, 28$-trihydroxyolean-12-en-30-oic acid, which was further confirmed by comparison of the NMR data for ring A of $\mathbf{1}$ with those of dillenic acid B. ${ }^{10}$
For the glycone part, the anomeric carbon signal at $\delta_{\mathrm{C}} 95.9$ showed correlation with proton at $\delta_{\mathrm{H}} 6.46(d, J=8.0 \mathrm{~Hz})$ in the HSQC spectrum. Detailed analysis of the HSQC, HMBC and ROESY data of 1 led to the assignment of a glucopyranosyl unit (Table 1). The $\beta$-configuration of the anomeric proton was confirmed by the large ${ }^{3} \mathrm{~J}_{\mathrm{H} 1-\mathrm{H} 2}$ coupling constant. The linkage position of the sugar unit was determined with the aid of HMBC data (Fig. 2), in which correlation between $\mathrm{H}-1$ of glucose $\left(\delta_{\mathrm{H}}\right.$ $6.46)$ and $\mathrm{C}-30$ of the aglycone $\left(\delta_{\mathrm{C}} 177.1\right)$ was clearly observed. In 


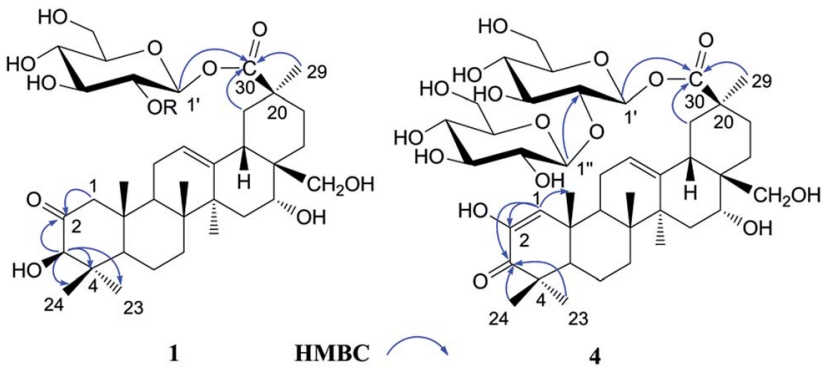

Fig. 2 Selected key HMBC correlations of 1 and 4 .

conclusion, all available evidence suggested the structure of 2oxo-3 $\beta, 16 \alpha, 28$-trihydroxy-olean-12-en-30-oic acid 30-O- $\beta$-D-glucopyranosyl ester for $\mathbf{1}$. It is noteworthy that the aglycone of $\mathbf{1}$ is reported for the first time.

Androside B (2) was isolated as an amorphous powder. The high resolution ESI-MS spectrum showed a quasi-molecular ion at $m / z$ 849.4259 $[\mathrm{M}+\mathrm{H}]^{+}$(calcd for $\mathrm{C}_{42} \mathrm{H}_{67} \mathrm{O}_{16}$ : 849.4243), consistent with the molecular formula $\mathrm{C}_{42} \mathrm{H}_{66} \mathrm{O}_{16}$. The ${ }^{1} \mathrm{H}$ NMR spectrum of 2 (Table 1 ) displayed six tertiary methyl signals at $\delta_{\mathrm{H}} 0.84,0.85,0.85,1.28,1.48$, and 1.80 (each s), an olefinic proton at $\delta_{\mathrm{H}} 5.79$ (br s), as well as two anomeric protons at 6.38 $\left(\mathrm{d}, J=8.0 \mathrm{~Hz}\right.$ ) and $5.53(\mathrm{~d}, J=8.0 \mathrm{~Hz})$. The ${ }^{13} \mathrm{C}$ NMR data (Table 1) were similar to those of $\mathbf{1}$ except for the appearance of an additional glucopyranosyl unit $\left(\delta_{\mathrm{C}} 105.6,76.4,78.2,71.4,78.4\right.$, 62.6). Acid hydrolysis of 2 afforded D-glucose only, which was identified by derivatization and HPLC analysis. Comparison of the NMR data of $\mathbf{2}$ with those of 1 revealed the downfield shift (+6.8 ppm) for C-2' of glucose, suggesting an additional glucopyranosyl residue at $\mathrm{C}-2^{\prime}$. This conclusion was supported by the HMBC correlation between $\mathrm{H}-1^{\prime \prime}\left(\delta_{\mathrm{H}}\right.$ 5.53) of the terminal glucose and $\mathrm{C}-2^{\prime}\left(\delta_{\mathrm{C}} 81.3\right)$ of the inner glucose. Based on the above evidence, 2 was determined to be 2 -oxo-3 $\beta, 16 \alpha, 28$ thihydroxy-olean-12-en-30-oic acid 30-O- $\beta$-D-glucopyranosyl $(1 \rightarrow$ 2)-glucopyranosyl ester.

The molecular formula of androside $\mathrm{C}$ (3) was determined to be $\mathrm{C}_{42} \mathrm{H}_{66} \mathrm{O}_{15}$ by HR-ESI-MS (833.4288 [M $\left.+\mathrm{Na}\right]^{+}$; calcd for $\mathrm{C}_{42} \mathrm{H}_{66} \mathrm{O}_{15} \mathrm{Na}$ : 833.4293). The ${ }^{1} \mathrm{H}$ and ${ }^{13} \mathrm{C}$ NMR spectral features of the aglycone (Table 2) were similar to those of 2, suggesting the same aglycone structure. For the glycone part of 3 , the presence of two sugar units was implied by the observation of two anomeric proton signals at $\delta_{\mathrm{H}} 6.32(\mathrm{~d}, J=8.0 \mathrm{~Hz})$ and 6.56 (br s), as well as two anomeric carbon signals at $\delta_{\mathrm{C}} 101.5$ and 94.5. Indeed, acid hydrolysis of 3 yielded L-rhamnose and $\mathrm{D}^{-}$ glucose. The anomeric configurations of D-glucose and L-rhamnose were determined to be $\beta$ and $\alpha$, respectively, based on the coupling constants of the anomeric protons and ${ }^{13} \mathrm{C}$ NMR data. ${ }^{12}$

The sequence and linkage of the sugars were then determined by $2 \mathrm{D}$ NMR analysis. Thus, HMBC cross peaks between $\mathrm{H}-\mathrm{1}^{\prime \prime}\left(\delta_{\mathrm{H}}\right.$ 6.56) of rhamnose and $\mathrm{C}-2^{\prime}\left(\delta_{\mathrm{C}} 76.1\right)$ of glucose, and between $\mathrm{H}-1^{\prime}$ of glucose $\left(\delta_{\mathrm{H}} 6.32\right)$ and $\mathrm{C}-30$ of the aglycone $\left(\delta_{\mathrm{C}} 177.3\right)$, were clearly observed. The above findings led to the assignment of 3 as 2 -oxo-3 $\beta, \quad 16 \alpha, 28$-thihydroxy-olean-12-en-30-oic acid $30-O-\alpha-\mathrm{L}^{-}$ rhamnopyrano $\operatorname{syl}(1 \rightarrow 2)$ - $\beta$-D-glucopyranosyl ester.

Androside D (4) was shown to possess a molecular formula $\mathrm{C}_{42} \mathrm{H}_{64} \mathrm{O}_{16}$ from its HR-ESI-MS data, $m / z$ 847.4088 $[\mathrm{M}+\mathrm{Na}]^{+}$ (calcd for $\mathrm{C}_{42} \mathrm{H}_{64} \mathrm{O}_{16} \mathrm{Na}$ : 847.4092). The IR spectrum displayed characteristic absorptions of hydroxyl $\left(3424 \mathrm{~cm}^{-1}\right)$, carboxyl $\left(1728 \mathrm{~cm}^{-1}\right)$ and olefinic bonds $\left(1642 \mathrm{~cm}^{-1}\right)$. In the UV spectrum, an absorption maximum at $270 \mathrm{~nm}$ indicated the presence of an $\alpha, \beta$-unsaturated ketone. The ${ }^{1} \mathrm{H}$ NMR spectrum of 4 (Table 1) displayed signals for six tertiary methyl groups $\left[\delta_{\mathrm{H}}\right.$ $0.92,1.10,1.11,1.19,1.49$ and 1.76 (each s)], two olefinic protons $\left[\delta_{\mathrm{H}} 6.52(\mathrm{~s})\right.$ and $\left.5.74(\mathrm{br} \mathrm{s})\right]$, and two anomeric protons $\left[\delta_{\mathrm{H}} 6.39(\mathrm{~d}, J=8.0 \mathrm{~Hz})\right.$ and $\left.5.55(\mathrm{~d}, J=8.0 \mathrm{~Hz})\right]$. In the ${ }^{13} \mathrm{C} \mathrm{NMR}$ and DEPT spectra (Table 1), 42 carbon signals (Table 1) were observed, of which 30 signals could be assigned to the aglycone. Comparison of the NMR data of $\mathbf{4}$ with those of 2 revealed the signals were almost identical, except for differences in ring A. The HMBC correlations between $\mathrm{C}-3\left(\delta_{\mathrm{C}} 201.1\right)$ and $\mathrm{H}-1\left(\delta_{\mathrm{H}}\right.$ $6.52) / \mathrm{H}-23\left(\delta_{\mathrm{H}} 1.19\right) / \mathrm{H}-24\left(\delta_{\mathrm{H}} 1.11\right)$ led to the assignment of a carbonyl at the $\mathrm{C}-3$ position (Fig. 2$)$. Furthermore, HMBC cross peaks between $\mathrm{H}-1\left(\delta_{\mathrm{H}} 6.52\right)$ and $\mathrm{C}-2\left(\delta_{\mathrm{C}} 146.3\right) / \mathrm{C}-5\left(\delta_{\mathrm{C}} 54.1\right) / \mathrm{C}-9$ $\left(\delta_{\mathrm{C}} 42.8\right) / \mathrm{C}-25\left(\delta_{\mathrm{C}} 22.1\right)$ revealed a double bond between $\mathrm{C}-1$ and $\mathrm{C}-2$, as well as a hydroxyl group at C-2 (Fig. 2). These conclusions could be further confirmed by the ROESY correlations between $\mathrm{H}-1\left(\delta_{\mathrm{H}} 6.52\right)$ and $\mathrm{H}-9\left(\delta_{\mathrm{H}} 2.04\right)$, and between $\mathrm{H}-1$ and $\mathrm{H}-25\left(\delta_{\mathrm{H}}\right.$ 1.10). Therefore, the aglycone of 4 was identified to be 3-oxo-2, $16 \alpha, 28$-trihydroxy-olean-1, 12-dien-30-oic acid.

For the glycone part, D-glucose was identified by acid hydrolysis and HPLC analysis. The NMR data for the sugar chain of $\mathbf{4}$ were identical to those of $\mathbf{2}$, indicating the presence of 30 - $O$ - $\beta$-D-glucopyranosyl $(1 \rightarrow 2)$-glucopyranosyl ester, which could be further verified by an HMBC experiment (Fig. 2). Thus, HMBC correlations between $\mathrm{H}-1\left(\delta_{\mathrm{H}} 6.52\right)$ of the outer glucose and C-2 $\left(\delta_{\mathrm{C}} 81.3\right)$ of the inner glucose, as well as between $\mathrm{H}-1\left(\delta_{\mathrm{H}}\right.$ $6.39)$ of the inner glucose and C-30 $\left(\delta_{\mathrm{C}} 177.2\right)$ of aglycone, were observed. Based on the above evidence, the structure of 4 was established to be 3-oxo-2,16 $\alpha, 28$-trihydroxy-olean-1,12-dien-30oic acid 30- $O$ - $\beta$-D-glucopyranosyl $(1 \rightarrow 2)$-glucopyranosyl ester.

The molecular formula of androside $\mathrm{E}$ (5) was assigned as $\mathrm{C}_{42} \mathrm{H}_{64} \mathrm{O}_{15}$ on the basis of its HR-ESI-MS data $(\mathrm{m} / \mathrm{z} 831.4143[\mathrm{M}+$ $\mathrm{Na}^{+}$; calcd for $\mathrm{C}_{42} \mathrm{H}_{64} \mathrm{O}_{15} \mathrm{Na}$ : 831.4137). The ${ }^{1} \mathrm{H}$ and ${ }^{13} \mathrm{C} \mathrm{NMR}$ spectra (Table 2) indicated that $\mathbf{5}$ was also a triterpene saponin bearing two sugar units. The NMR data of $\mathbf{5}$ were similar to those of 4 , except the signals of glucopyranosyl in $4\left(\delta_{\mathrm{C}} 105.6\right.$, $76.4,78.2,71.4,78.4$ and 62.5) were now replaced by those of a rhamnopyranosyl unit (101.5, 72.5, 72.5, 73.9, 69.8 and 18.8). Acid hydrolysis of $\mathbf{5}$ yielded D-glucose and L-rhamnose. The chemical shifts and $J$ values of the anomeric protons indicated the $\beta$-configuration of glucopyranosyl and $\alpha$-configuration of rhamnopyranosyl units. In the HMBC spectrum, cross-peaks were observed between $\mathrm{H}-1\left(\delta_{\mathrm{H}} 6.58\right)$ of rhamnose and $\mathrm{C}-2\left(\delta_{\mathrm{C}}\right.$ 76.2) of glucose, as well as between $\mathrm{H}-1\left(\delta_{\mathrm{H}} 6.34\right)$ of glucose and C-30 $\left(\delta_{\mathrm{C}} 177.2\right)$ of aglycone. Thus, the structure of 5 was determined to be 3-oxo-2, 16 $\alpha, 28$-trihydroxy-olean-1,12-dien-30-oic acid 30-O- $\alpha$-L-rhamnopy $\operatorname{ranosyl}(1 \rightarrow 2)-\beta$-D-glucopyranosyl ester. It is noteworthy that the new aglycone structure in $\mathbf{4}$ and $\mathbf{5}$ is reported for the first time.

The molecular formula of androside $\mathrm{F}(\mathbf{6})$ was determined to be $\mathrm{C}_{48} \mathrm{H}_{78} \mathrm{O}_{20}$ by its HR-ESI-MS spectrum $(\mathrm{m} / \mathrm{z} 1009.4775[\mathrm{M}+$ $\mathrm{Cl}]^{-}$; calcd for $\left.\mathrm{C}_{48} \mathrm{H}_{78} \mathrm{O}_{20} \mathrm{Cl}, 1009.4775\right)$. The ${ }^{1} \mathrm{H}$ and ${ }^{13} \mathrm{C} \mathrm{NMR}$ spectroscopic data of the aglycone (Table 2) were in good 
Table $2{ }^{1} \mathrm{H}$ NMR and ${ }^{13} \mathrm{C}$ NMR spectroscopic data of compounds 3,5 and $6\left(\delta \text { in ppm, } \mathrm{J} \text { in } \mathrm{Hz}, \mathrm{C}_{5} \mathrm{D}_{5} \mathrm{~N}\right)^{a, b}$

\begin{tabular}{|c|c|c|c|c|c|c|}
\hline \multirow[b]{2}{*}{ Position } & \multicolumn{2}{|l|}{3} & \multicolumn{2}{|l|}{5} & \multicolumn{2}{|l|}{6} \\
\hline & $\delta_{\mathrm{H}}$ & $\delta_{\mathrm{C}}$ & $\delta_{\mathrm{H}}$ & $\delta_{\mathrm{C}}$ & $\delta_{\mathrm{H}}$ & $\delta_{\mathrm{C}}$ \\
\hline 1 & $2.17,2.46, \mathrm{~m}$ & $53.8, \mathrm{CH}_{2}$ & $6.54, \mathrm{~s}$ & $129.5 \mathrm{~d}$ & $0.88,1.41, \mathrm{~m}$ & $38.9, \mathrm{CH}_{2}$ \\
\hline 2 & - & 211.1, C & - & $146.3, \mathrm{C}$ & $2.18,1.78, \mathrm{~m}$ & 26.6, $\mathrm{CH}_{2}$ \\
\hline 3 & $4.18, \mathrm{~s}$ & $83.3, \mathrm{CH}$ & - & 201.1, C & $3.27, \mathrm{dd}(8.0,2.0)$ & $88.9, \mathrm{CH}$ \\
\hline 4 & - & $45.7, \mathrm{C}$ & - & $44.6, \mathrm{C}$ & - & $39.5, \mathrm{C}$ \\
\hline 5 & $1.56, \mathrm{~m}$ & $54.8, \mathrm{CH}$ & $1.65, \mathrm{~m}$ & $54.1, \mathrm{CH}$ & $0.71, \mathrm{~d}(11.7)$ & $55.8, \mathrm{CH}$ \\
\hline 6 & - & 18.9, $\mathrm{CH}_{2}$ & - & 19.1, $\mathrm{CH}_{2}$ & $1.42,1.29, \mathrm{~m}$ & $18.4, \mathrm{CH}_{2}$ \\
\hline 7 & $1.34,1.68, \mathrm{~m}$ & $32.8, \mathrm{CH}_{2}$ & $1.34,1.68, \mathrm{~m}$ & $33.0, \mathrm{CH}_{2}$ & $1.56,1.27, \mathrm{~m}$ & $33.2, \mathrm{CH}_{2}$ \\
\hline 8 & - & $40.3, \mathrm{C}$ & - & $40.6, \mathrm{C}$ & - & $40.0, \mathrm{C}$ \\
\hline 9 & $2.02, \mathrm{t}(9.8)$ & $46.8, \mathrm{CH}$ & $2.04, \mathrm{~m}$ & $42.8, \mathrm{CH}$ & $1.66, \mathrm{t}(8.9)$ & $47.0, \mathrm{CH}$ \\
\hline 10 & - & $43.4, \mathrm{C}$ & - & $38.4, \mathrm{C}$ & - & $36.8, \mathrm{C}$ \\
\hline 11 & $1.76, \mathrm{~m}$ & 23.7, $\mathrm{CH}_{2}$ & $1.9,2.05, \mathrm{~m}$ & $23.8, \mathrm{CH}_{2}$ & $1.78, \mathrm{~m}$ & 23.7, $\mathrm{CH}_{2}$ \\
\hline 12 & 5.79, br s & $122.4, \mathrm{CH}$ & 5.84, br s & $122.6, \mathrm{CH}$ & 5.64, br s & 123.1, $\mathrm{CH}$ \\
\hline 13 & - & $144.8, \mathrm{C}$ & - & 145.0, C & - & $144.7, \mathrm{C}$ \\
\hline 14 & - & $41.9, \mathrm{C}$ & - & $42.2, \mathrm{C}$ & - & $41.7, \mathrm{C}$ \\
\hline 15 & $\begin{array}{l}1.63, \text { br d }(14.2) \\
2.18, \text { br d }(12.2)\end{array}$ & $34.9, \mathrm{CH}_{2}$ & $1.60,2.18, \mathrm{~m}$ & $34.8, \mathrm{CH}_{2}$ & $1.61,2.19$ & $34.9, \mathrm{CH}_{2}$ \\
\hline 16 & 4.62, br s & $74.0, \mathrm{CH}$ & 4.62, br s & $74.1, \mathrm{CH}$ & 4.66, br s & $74.2, \mathrm{CH}$ \\
\hline 17 & & $40.5, \mathrm{C}$ & - & $40.6, \mathrm{C}$ & - & $40.4, \mathrm{C}$ \\
\hline 18 & $2.88, \mathrm{~m}$ & $42.8, \mathrm{CH}$ & $2.88, \mathrm{~m}$ & $43.0, \mathrm{CH}$ & $2.74, \mathrm{~m}$ & $43.2, \mathrm{CH}$ \\
\hline 19 & $2.49,2.91, \mathrm{~m}$ & 44.1, $\mathrm{CH}_{2}$ & $2.45,2.91, \mathrm{~m}$ & $44.0 \mathrm{t}$ & $2.34,2.78, \mathrm{~m}$ & 44.7, $\mathrm{CH}_{2}$ \\
\hline 20 & - & $44.7, \mathrm{C}$ & - & $44.6, \mathrm{C}$ & - & $44.7, \mathrm{C}$ \\
\hline 21 & $2.50, \mathrm{~m}$ & $33.9, \mathrm{CH}_{2}$ & $2.50, \mathrm{~m}$ & $33.9, \mathrm{CH}_{2}$ & $2.49,1.58, \mathrm{~m}$ & $33.6, \mathrm{CH}_{2}$ \\
\hline 22 & $2.35,2.43, \mathrm{~m}$ & $31.8, \mathrm{CH}_{2}$ & $2.35,2.43, \mathrm{~m}$ & $31.8, \mathrm{CH}_{2}$ & $2.58,2.34, \mathrm{~m}$ & $31.8, \mathrm{CH}_{2}$ \\
\hline 23 & $1.29, \mathrm{~s}$ & 29.4, $\mathrm{CH}_{3}$ & $1.20, \mathrm{~s}$ & $27.8, \mathrm{CH}_{3}$ & $1.25, \mathrm{~s}$ & $28.1, \mathrm{CH}_{3}$ \\
\hline 24 & $0.84, \mathrm{~s}$ & $17.3, \mathrm{CH}_{3}$ & $1.10, \mathrm{~s}$ & $20.2, \mathrm{CH}_{3}$ & $1.09, \mathrm{~s}$ & $16.9, \mathrm{CH}_{3}$ \\
\hline 25 & $0.85, \mathrm{~s}$ & 16.6, $\mathrm{CH}_{3}$ & $1.12, \mathrm{~s}$ & 22.1, $\mathrm{CH}_{3}$ & $0.82, \mathrm{~s}$ & $15.7, \mathrm{CH}_{3}$ \\
\hline 26 & $0.86, \mathrm{~s}$ & $16.5, \mathrm{CH}_{3}$ & $0.93, \mathrm{~s}$ & $17.4, \mathrm{CH}_{3}$ & $0.87, \mathrm{~s}$ & $16.8, \mathrm{CH}_{3}$ \\
\hline 27 & $1.81, \mathrm{~s}$ & $27.3, \mathrm{CH}_{3}$ & $1.77, \mathrm{~s}$ & $27.1, \mathrm{CH}_{3}$ & $1.81, \mathrm{~s}$ & $27.4, \mathrm{CH}_{3}$ \\
\hline 28 & 3.62 , dd $(8.2,2.0)$ & $69.8, \mathrm{CH}_{2}$ & 3.62 , dd $(8.2,2.0)$ & $70.1, \mathrm{CH}_{2}$ & $3.65, \mathrm{dd}(8.2,2.0)$ & $70.0, \mathrm{CH}_{2}$ \\
\hline 29 & $1.54, \mathrm{~s}$ & $28.4, \mathrm{CH}_{3}$ & $1.54, \mathrm{~s}$ & $28.4, \mathrm{CH}_{3}$ & $1.37, \mathrm{~s}$ & $28.6, \mathrm{CH}_{3}$ \\
\hline 30 & - & $177.3, \mathrm{C}$ & - & $177.2, \mathrm{C}$ & - & 177.1, C \\
\hline $\mathrm{Glc1}^{\prime}$ & $6.32, \mathrm{~d}(8.0)$ & $94.5, \mathrm{CH}$ & $6.34, \mathrm{~d}(8.0)$ & $94.5, \mathrm{CH}$ & $4.88, \mathrm{~d}(7.5)$ & $105.0, \mathrm{CH}$ \\
\hline $2^{\prime}$ & $4.51, \mathrm{t}(8.8)$ & $76.1, \mathrm{CH}$ & $4.53, \mathrm{~m}$ & $76.2, \mathrm{CH}$ & 4.21, dd (2.8.8.8) & $83.4, \mathrm{CH}$ \\
\hline $3^{\prime}$ & $4.32, \mathrm{t}(9.0)$ & $78.6, \mathrm{CH}$ & $4.33, \mathrm{~m}$ & $79.7, \mathrm{CH}$ & $4.25, \mathrm{dd}(4.0 .9 .0)$ & $77.9, \mathrm{CH}$ \\
\hline $4^{\prime}$ & $4.23, \mathrm{~m}$ & $71.7, \mathrm{CH}$ & $4.24, \mathrm{~m}$ & $71.8, \mathrm{CH}$ & $4.11, \mathrm{t}(9.3)$ & $71.7, \mathrm{CH}$ \\
\hline $5^{\prime}$ & $3.96, \mathrm{~m}$ & $79.7, \mathrm{CH}$ & $3.97, \mathrm{~m}$ & 78.6, CH & $3.88, \mathrm{~m}$ & $78.3, \mathrm{CH}$ \\
\hline $6^{\prime}$ & $\begin{array}{l}\text { 4.26, m 4.36, } \\
\text { dd (2.5.11.8) }\end{array}$ & $62.4, \mathrm{CH}_{2}$ & $\begin{array}{l}4.26, \text { br d }(9.4) \\
4.36, \text { br d }(11.4)\end{array}$ & 62.6, $\mathrm{CH}_{2}$ & $\begin{array}{l}4.42, \text { br d }(10.0) \\
4.51, \mathrm{dd}(2.3 .11 .7)\end{array}$ & $62.7, \mathrm{CH}_{2}$ \\
\hline Glc1" & & & & & $5.34, \mathrm{~d}(7.5)$ & $106.0, \mathrm{CH}$ \\
\hline $2^{\prime \prime}$ & & & & & $4.09, \mathrm{t}(9.0)$ & $77.1, \mathrm{CH}$ \\
\hline $3^{\prime \prime}$ & & & & & 4.21, dd $(2.8 .8 .8)$ & $78.2, \mathrm{CH}$ \\
\hline $4^{\prime \prime}$ & & & & & $4.11, \mathrm{t}(9.3)$ & $71.6, \mathrm{CH}$ \\
\hline $5^{\prime \prime}$ & & & & & $3.88, \mathrm{~m}$ & $77.9, \mathrm{CH}$ \\
\hline $6^{\prime \prime}$ & & & & & $\begin{array}{l}\text { 4.42, br d (10.0) } \\
4.45, \mathrm{dd}(3.2 .11 .5)\end{array}$ & $62.8, \mathrm{CH}_{2}$ \\
\hline Rha $1^{\prime \prime}$ & $6.56, \mathrm{~s}$ & 101.5, CH & 6.56 , br s & 101.5, CH & & \\
\hline $2^{\prime \prime}$ & $4.73, \mathrm{~m}$ & $72.5, \mathrm{CH}$ & $4.74, \mathrm{~m}$ & $72.5, \mathrm{CH}$ & & \\
\hline $3^{\prime \prime}$ & $4.52, \mathrm{t}(8.8)$ & $72.5, \mathrm{CH}$ & $4.53, \mathrm{~m}$ & $72.5, \mathrm{CH}$ & & \\
\hline $4^{\prime \prime}$ & $4.28, \mathrm{~m}$ & $74.1, \mathrm{CH}$ & 4.28, br d $(7.9)$ & $73.9, \mathrm{CH}$ & & \\
\hline $5^{\prime \prime}$ & 4.66, dd $(6.2,9.4)$ & $70.1, \mathrm{CH}$ & $4.66, \mathrm{dd}(6.2,9.9)$ & $69.8, \mathrm{CH}$ & & \\
\hline $6^{\prime \prime}$ & $1.73, \mathrm{~d}(6.1)$ & $18.8, \mathrm{CH}_{3}$ & $1.73, \mathrm{~d}(6.1)$ & $18.8, \mathrm{CH}_{3}$ & & \\
\hline Glc $1^{\prime \prime \prime}$ & & & & & $6.45, \mathrm{~d}(8.0)$ & $95.9, \mathrm{CH}$ \\
\hline $2^{\prime \prime \prime}$ & & & & & 4.21, dd (2.8.8.8) & $74.4, \mathrm{CH}$ \\
\hline $3^{\prime \prime \prime}$ & & & & & $4.29, \mathrm{t}(7.5)$ & $78.6, \mathrm{CH}$ \\
\hline $4^{\prime \prime \prime}$ & & & & & $4.30, \mathrm{t}(6.9)$ & $71.2, \mathrm{CH}$ \\
\hline $5^{\prime \prime \prime}$ & & & & & $3.99, \mathrm{~m}$ & $79.3, \mathrm{CH}$ \\
\hline $6^{\prime \prime \prime}$ & & & & & $\begin{array}{l}4.33, \text { dd }(4.8 .11 .8) \\
4.42, \text { br d }(10.0)\end{array}$ & $62.4, \mathrm{CH}_{2}$ \\
\hline
\end{tabular}

${ }^{a}{ }^{1} \mathrm{H}$ NMR Spectrum was measured at $500 \mathrm{MHz} ;{ }^{13} \mathrm{C}$ NMR Spectrum was measured at $125 \mathrm{MHz} .{ }^{b}$ Overlapping signals were reported without designating multiplicity. 
agreement with those of ardisicrenoside $\mathrm{C}^{\mathbf{1 1}}$ The $\beta$-configuration of $3-\mathrm{OH}$ and $\alpha$-configuration of $16-\mathrm{OH}$ were deduced by the coupling constants of $\mathrm{H}-3$ (dd, $J=8.0,2.0 \mathrm{~Hz}$ ) and $\mathrm{H}-16(\mathrm{br} \mathrm{s})$, respectively. Thus, the aglycone of 6 was determined to be jac-

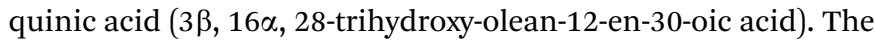
NMR data for the sugar moiety and GC analysis of the derivatives of its acid hydrolysateled to the assignment of three $\beta$-Dglucopyranose units. Connectivity of the sugars was determined on the basis of HMBC data. Thus, correlations between $\mathrm{H}-1$ of the inner glucose $\left[\delta_{\mathrm{H}} 4.88(1 \mathrm{H}, \mathrm{d}, J=7.5 \mathrm{~Hz})\right]$ and $\mathrm{C}-3$ of the aglycone $\left(\delta_{\mathrm{C}} 88.9\right)$, between $\mathrm{H}-1$ of the outer glucose $\left[\delta_{\mathrm{H}} 5.34\right.$ $(1 \mathrm{H}, \mathrm{d}, J=7.5 \mathrm{~Hz})]$ and $\mathrm{C}-2$ of the inner glucose $\left(\delta_{\mathrm{C}} 83.4\right)$, as well as between $\mathrm{H}-1$ of the third glucose $\left[\delta_{\mathrm{H}} 6.45(1 \mathrm{H}, \mathrm{d}, J=8.0 \mathrm{~Hz})\right]$ and $\mathrm{C}-30\left(\delta_{\mathrm{C}} 177.1\right)$ of the aglycone, were observed. These data revealed the structure of sugar chain as shown in Fig. 1, which was further confirmed by comparison of the NMR data with those of asteryunnanoside $\mathrm{I}^{13}$ Consequently, the structure of 6 was elucidated to be $3-O$ - $\beta$-D-glucopyranosyl $(1 \rightarrow 2)$ - $\beta$-D-glucopyranosyl $3 \beta, 16 \alpha, 28$-trihydroxy-olean-12-en-30-oic acid $30-O-\beta$ D-glucopyranosyl ester.

\section{Cytotoxicity}

The cytotoxicity of $\mathbf{1 - 8}$ was tested in human hepatoma carcinoma cell lines (HepG2 and HepG2/ADM) and human breast cancer cell lines (MCF-7, MCF-7/ADR and MDA-MB-231) by MTT assay. As shown in Table 3, among the tested compounds, only 7 and 8 bearing a 13 $\beta, 28$-epoxy group exhibited inhibitory activity in these cancer cell lines, with $\mathrm{IC}_{50}$ values in the range of 36.19-51.86 $\mu \mathrm{M}$ and 9.29-17.71 $\mu \mathrm{M}$, respectively. It was observed that the drug resistant cancer cell line HepG2/ADM was more sensitive to compound $\mathbf{8}$ than its parental cell line HepG2, while the sensitivities of MCF-7, MCF-7/ADR and MDAMB-231 towards compound 8 were almost equivalent. Compound 7 exhibited similar cytotoxic activities in all tested cell lines.

In the presence of compound 8, an increase in sub-G $\mathrm{G}_{1} \mathrm{DNA}$ content was observed in HepG2/ADM cells after $72 \mathrm{~h}$ treatment in a dose-dependent manner (Fig. 3A). Apoptosis was analyzed by Annexin V-FITC/PI double staining assay and the population
A
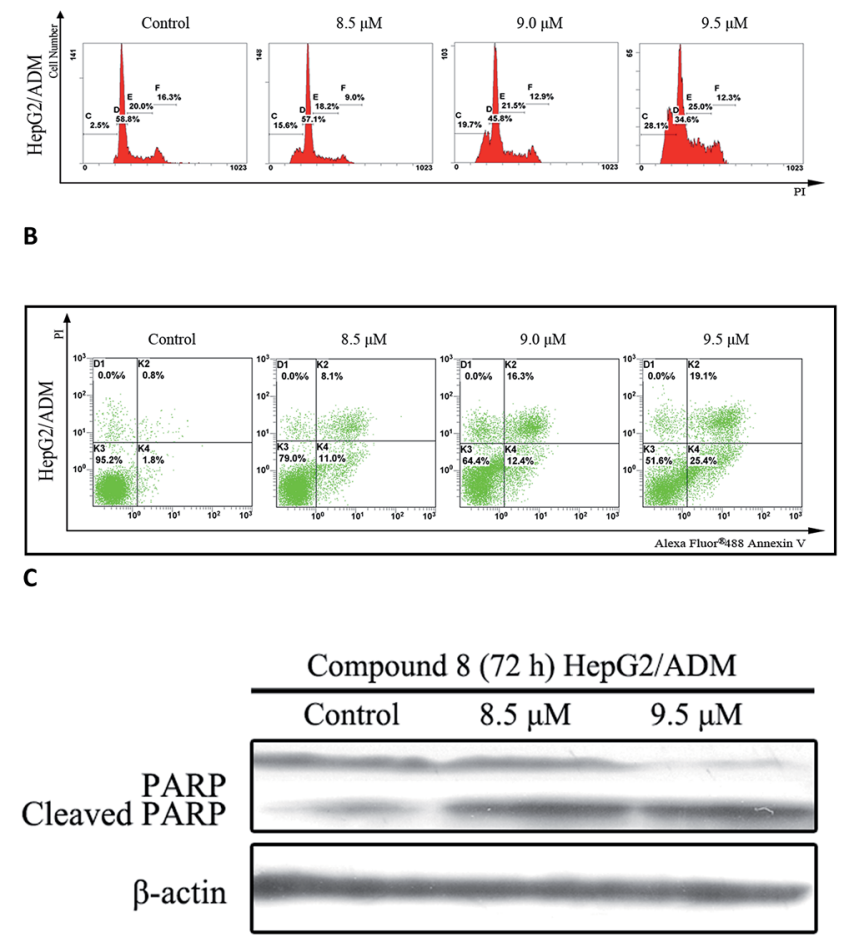

Fig. 3 Apoptosis induced by 8 in HepG2/ADM cells. (A) Flow cytometric analysis of DNA content of HepG2/ADM cells treated with 8 ( 8.5 $\mu \mathrm{M}, 9.0 \mu \mathrm{M}$ and $9.5 \mu \mathrm{M})$ for $72 \mathrm{~h}$. (B) Flow cytometry analysis of apoptotic rate of HepG2/ADM cells induced by $8(8.5 \mu \mathrm{M}, 9.0 \mu \mathrm{M}$ and $9.5 \mu \mathrm{M})$ for $72 \mathrm{~h}$. (C) Western blot analysis of cleaved PARP in HepG2/ ADM cells after treatment with $8(8.5 \mu \mathrm{M}$ and $9.5 \mu \mathrm{M})$ for $72 \mathrm{~h}$. $\beta$-actin served as a loading control.

of apoptotic cells was quantified. As shown in Fig. 3B, the population of early and late apoptotic cells was increased from $19.1 \%$ to $44.5 \%$ in a dose-dependent manner. Compound 8 also induced PARP cleavage (Fig. 3C), a marker of apoptosis. ${ }^{14}$ Taken together, the findings suggested that compound 8 induced apoptosis in HepG2/ADM cells.

Table 3 The cytotoxic activities of compounds 1-8 in HepG2, HepG2/ADM, MCF-7, MCF-7/ADM and MDA-MB-231 cancer cells ${ }^{a}$

\begin{tabular}{|c|c|c|c|c|c|}
\hline \multirow[b]{2}{*}{ Compounds } & \multicolumn{5}{|c|}{$\mathrm{IC}_{50}(\bar{x} \pm \mathrm{SD}) \mu \mathrm{M}^{b}$} \\
\hline & HepG2 & HepG2/ADM & MCF-7 & MCF-7/ADR & MDA-MB-231 \\
\hline 1 & $>200$ & $>200$ & $>200$ & $>200$ & $>200$ \\
\hline 2 & $>200$ & $>200$ & $>200$ & $>200$ & $>200$ \\
\hline 3 & $>200$ & $>200$ & $>200$ & $>200$ & $>200$ \\
\hline 6 & $>200$ & $>200$ & $>200$ & $>200$ & $>200$ \\
\hline 7 & $40.34 \pm 2.51$ & $36.19 \pm 2.57$ & $42.57 \pm 3.75$ & $43.86 \pm 2.50$ & $51.86 \pm 5.86$ \\
\hline 8 & $17.71 \pm 0.62$ & $9.97 \pm 0.46$ & $10.32 \pm 0.13$ & $10.52 \pm 1.13$ & $9.29 \pm 0.32$ \\
\hline
\end{tabular}

${ }^{a}$ Cytotoxic activities of compounds 1-8 were tested by using MTT assay. All data are presented as means \pm standard deviation of at least three independent experiments. ${ }^{b} \mathrm{IC}_{50}$ : concentration of the tested compound inhibiting $50 \%$ cell growth. ${ }^{c}$ DOX: doxorubicin was used as positive control. 


\section{Experimental section}

\section{General experimental procedures}

Melting points were measured on an X-4 micro melting point apparatus (without correction). Optical rotations were obtained by a Jasco P-1020 digital polarimeter in a $0.1 \mathrm{dm}$ length cell. IR spectra were determined on a Nicolet Impact 410 plus infrared spectrometer with $\mathrm{KBr}$ disc. 1D and 2D NMR experiments were performed on a Bruker AV-500 spectrometer using pyridine-d5 as solvent with tetramethylsilane (TMS) as internal reference. ESI-MS data were carried out on a HP-1100 LC/EST mass spectrometer. HR-ESI-MS data were measured on an Agilent 6210 ESI/TOF mass spectrometer. TLC was performed on precoated silica gel GF254 (Yantai Chemical Industry Research Institute, P. R. China) and precoated RP-18 F254 S plates (Merck). Silica gel (200-300 mesh; Qingdao Marine Chemical Factory, P. R. China), octadecylsilanized silica gel (ODS, YMC Co. Ltd.) and Sephadex LH-20 (Pharmacia Biotec AB) were used for column chromatographies. D-Glucose, L-glucose, D-rhamnose, and Lrhamnose were obtained from Sigma-Aldrich (USA).

\section{Plant material}

The fresh aerial parts of Androsace umbellata (Lour.) Merr. were collected in Nanjing city, Jiangsu Province of P. R. China, in March of 2004, and were authenticated by Prof. Min-Jian Qin (China Pharmaceutical University). A voucher specimen (no. 20040316) was deposited in the herbarium of China Pharmaceutical University, Nanjing, P. R. China.

\section{Extraction and isolation}

The fresh aerial parts of $A$. umbellata $(2.5 \mathrm{~kg})$ were pulverized and extracted with $70 \%$ EtOH three times (each $2 \mathrm{~h}$ ) under reflux. The extract was concentrated under vacuum and suspended in $\mathrm{H}_{2} \mathrm{O}$, then successively extracted with petroleum ether, EtOAc and $n$ $\mathrm{BuOH}$. The $n$-BuOH extract (100 g) was separated by silica gel column chromatography eluted with gradient $\mathrm{CHCl}_{3}-\mathrm{CH}_{3} \mathrm{OH}$ $(85: 15 \rightarrow 1: 1, \mathrm{v} / \mathrm{v})$ to give six fractions (A-E). Fraction A (10 g) was chromatographied on silica gel eluting with $\mathrm{CHCl}_{3}-\mathrm{CH}_{3} \mathrm{OH}$ (95: $5 \rightarrow 85: 15, \mathrm{v} / \mathrm{v}$ ) and purified by ODS column chromatography $\left[\mathrm{CH}_{3} \mathrm{OH}-\mathrm{H}_{2} \mathrm{O}(40: 60 \rightarrow 75: 25, \mathrm{v} / \mathrm{v})\right]$ to afford 1 (22 mg), 2 $(12 \mathrm{mg})$ and $4(13 \mathrm{mg})$. Fraction $\mathrm{B}(5 \mathrm{~g})$ was subjected to silica gel eluting with $\mathrm{CHCl}_{3}-\mathrm{CH}_{3} \mathrm{OH}(95: 5 \rightarrow 80: 20, \mathrm{v} / \mathrm{v}$ ), then separated by ODS column chromatography $\left[\mathrm{CH}_{3} \mathrm{OH}-\mathrm{H}_{2} \mathrm{O}(45: 55 \rightarrow\right.$ $80: 20, \mathrm{v} / \mathrm{v})$ ] to obtain $3(16 \mathrm{mg})$ and $5(10 \mathrm{mg})$. Fraction $\mathrm{C}(3.5 \mathrm{~g})$ was subjected to ODS column chromatography $\left[\mathrm{CH}_{3} \mathrm{OH}-\mathrm{H}_{2} \mathrm{O}\right.$ $(45: 55 \rightarrow 80: 20, \mathrm{v} / \mathrm{v})]$, and purified by Sephadex LH-20 $\left(\mathrm{CH}_{3} \mathrm{OH}\right)$ to yield $6(21 \mathrm{mg})$. Fraction D $(15 \mathrm{~g})$ was separated by silica gel and eluted with $\mathrm{CHCl}_{3}-\mathrm{CH}_{3} \mathrm{OH}(90: 10 \rightarrow 1: 1, \mathrm{v} / \mathrm{v})$ to give five subfractions (D1-D5). Compounds 7 (23 mg) and 8 (48 $\mathrm{mg}$ ) were obtained from subfraction D3 by ODS column chromatography $\left[\mathrm{CH}_{3} \mathrm{OH}-\mathrm{H}_{2} \mathrm{O}(35: 65 \rightarrow 77: 25, \mathrm{v} / \mathrm{v})\right]$.

\section{Characterization of new compounds}

Androside A (1). Amorphous powder; $[\alpha]_{\mathrm{D}}^{23}=+138.00(c$ 0.092, MeOH); IR (KBr) $\nu_{\text {max }}: 3442,2928,1726,1646,1458,1376$,
1319, 1205, 1070, 825, $562 \mathrm{~cm}^{-1}$; for ${ }^{1} \mathrm{H}$ NMR and ${ }^{13} \mathrm{C}$ NMR spectroscopic data, see Table 1; HR-ESI-MS m/z: $687.3709[\mathrm{M}+$ $\mathrm{Na}]^{+}$(calculated for $\mathrm{C}_{36} \mathrm{H}_{56} \mathrm{O}_{11} \mathrm{Na}, 687.3714$ ).

Androside B (2). Amorphous powder; $[\alpha]_{\mathrm{D}}^{23}=+47.08(c$ 0.130, $\mathrm{MeOH})$; IR (KBr) $\nu_{\text {max }}: 3442,2925,1712,1632,1463,1378,1258$, 1203, $1067 \mathrm{~cm}^{-1}$; for ${ }^{1} \mathrm{H}$ NMR and ${ }^{13} \mathrm{C}$ NMR spectroscopic data, see Table 1; HR-ESI-MS m/z: 849.4259 [M + Na $]^{+}$(calculated for $\left.\mathrm{C}_{42} \mathrm{H}_{67} \mathrm{O}_{16} \mathrm{Na}, 849.4243\right)$.

Androside C (3). Amorphous powder; $[\alpha]_{\mathrm{D}}^{23}=+35.61(c 0.132$, $\mathrm{MeOH})$; IR (KBr) $\nu_{\text {max }}: 3425,2972$, 2929, 1760, 1723, 1636, 1461, 1393, 1374, 1316, 1258, 1059, 626, $560 \mathrm{~cm}^{-1}$; for ${ }^{1} \mathrm{H}$ NMR and ${ }^{13} \mathrm{C}$ NMR spectroscopic data, see Table 2; HR-ESI-MS $\mathrm{m} / \mathrm{z}$ : 833.4288 $[\mathrm{M}+\mathrm{Na}]^{+}$(calculated for $\mathrm{C}_{42} \mathrm{H}_{66} \mathrm{O}_{15} \mathrm{Na}, 833.4293$ ).

Androside D (4). Amorphous powder; $[\alpha]_{\mathrm{D}}^{23}=+80.28(c 0.085$, $\mathrm{MeOH}$ ); IR (KBr) $\nu_{\text {max }}: 3424,2923,1630,1451,1382,1163,1074$, 1044, 995, $607 \mathrm{~cm}^{-1}$; for ${ }^{1} \mathrm{H}$ NMR and ${ }^{13} \mathrm{C}$ NMR spectroscopic data, see Table 1; HR-ESI-MS $m / z: 847.4088[\mathrm{M}+\mathrm{Na}]^{+}$(calculated for $\mathrm{C}_{42} \mathrm{H}_{64} \mathrm{O}_{16} \mathrm{Na}$, 847.4092).

Androside E (5). Amorphous powder; $[\alpha]_{\mathrm{D}}^{23}=+92.00(c 0.030$, $\mathrm{MeOH})$; IR (KBr) $\nu_{\text {max }}: 3424,2928,1728,1642,1459,1403,1383$, 1320, 1236, 1077, 893, 628, $565 \mathrm{~cm}^{-1}$; for ${ }^{1} \mathrm{H}$ NMR and ${ }^{13} \mathrm{C}$ NMR spectroscopic data, see Table 2; HR-ESI-MS m/z: $831.4143[\mathrm{M}+$ $\mathrm{Na}]^{+}$(calculated for $\mathrm{C}_{42} \mathrm{H}_{64} \mathrm{O}_{15} \mathrm{Na}, 831.4137$ ).

Androside F (6). Amorphous powder; $[\alpha]_{\mathrm{D}}^{23}=+40.38(c 0.052$, $\mathrm{MeOH}$ ); IR (KBr) $\nu_{\text {max }}: 3424,2926,1730,1642,1460,1384,1203$, $1077,629 \mathrm{~cm}^{-1}$; for ${ }^{1} \mathrm{H}$ NMR and ${ }^{13} \mathrm{C}$ NMR spectroscopic data, see Table 2; HR-ESI-MS $m / z: 1009.4775[\mathrm{M}+\mathrm{Cl}]^{-}$(calculated for $\left.\mathrm{C}_{48} \mathrm{H}_{78} \mathrm{O}_{20} \mathrm{Cl}, 1009.4775\right)$.

\section{HPLC analysis for sugar residues}

Each compound $(2 \mathrm{mg})$ was dissolved in $4 \mathrm{~mol} \mathrm{~L}^{-1} \mathrm{HCl}(10 \mathrm{~mL})$ and heated at $90^{\circ} \mathrm{C}$ in water bath for $6 \mathrm{~h}$. After reaction product was dissolved in $\mathrm{H}_{2} \mathrm{O}$. The mixture was extracted with EtOAc for three times. The aqueous layer containing sugars was concentrated to dryness, mixed with L-cysteine methyl ester hydrochloride, and heated at $60^{\circ} \mathrm{C}$ in an oven in the presence of anhydrous pyridine $(1 \mathrm{~mL})$ for $1 \mathrm{~h}$. Isothiocyanate $(2 \mathrm{mg})$ was then added to the mixture and heated at $60{ }^{\circ} \mathrm{C}$ for another hour. Each reaction mixture was analyzed by HPLC under the following conditions: an Agilent 1200 chromatograph equipped with a Cosmosil $5 \mathrm{C}_{18^{-}}$ MS-II column (4.6 × $250 \mathrm{~mm}$ i.d., Nacalai Tesque Inc.); mobile phase: isocratic elution of $25 \% \mathrm{CH}_{3} \mathrm{CN}-\mathrm{H}_{2} \mathrm{O}$ in $50 \mathrm{mmol} \mathrm{L}^{-1} \mathrm{HCl}$; flow rate: $0.8 \mathrm{~mL} \mathrm{~min}^{-1}$; injection volume: $10 \mu \mathrm{L}$; column temperature: $35{ }^{\circ} \mathrm{C}$; UV detection wavelength: $250 \mathrm{~nm}$. The standard L-rhamnose, D-rhamnose, D-glucose, L-glucose, D-xylose, L-xylose, L-arabinose and D-arabinose were run under the same conditions. Comparison of the retention time of the monosaccharide derivatives led to the determination of D-glucose (19.2 $\mathrm{min}$ ) and L-rhamnose (32.6 $\mathrm{min})$.

\section{Cell cytotoxicity assay}

Reagents. Doxorubicin (Dox), [3-(4,5)-dimethylthiazol-2-yl2,5-diphenyl tetrazolium bromide] (MTT), propidium iodide (PI) and Ribonuclease A (RNase A) were obtained from SigmaAldrich (St. Louis, MO, USA). Annexin V-FITC/PI double staining assay kit was purchased from Biouniquer Tech (Jiangsu, 
China). Antibodies against PARP were supplied by Santa Cruz Biotechnology (Santa Cruz, CA, USA). Antibodies against $\beta$-actin as well as Goat anti-Rabbit IgG H\&L second antibody were obtained from Cell Signaling Technology (Beverly, MA, USA). BCA protein assay kit was purchased from Thermo Fisher Scientific (Rockford, IL, USA). Other chemicals were supplied by SigmaAldrich (St. Louis, MO, USA).

Cell culture. Human hepatocellular carcinoma cell line HepG2 was obtained from the American Type Culture Collection (Manassas, VA, USA). The Dox-resistant cancer cell lines, HepG2/ADM, was kindly provided by Professor Kwok-Pui Fung (School of Biomedical Sciences, The Chinese University of Hong Kong). Human breast cancer cell line MCF-7 (estrogen-positive) and Dox-resistant cancer cell lines MCF-7/ADR were kindly supplied by Professor Li-Wu Fu (Cancer Center, Sun Yat-Sen University). The human breast cancer cell lines MDA-MB-231 (estrogen-negative) was purchased from Cell Bank, Shanghai Institutes for Biological Sciences (Chinese Academy of Sciences, Shanghai, China). All cells were cultured in RPMI-1640 medium supplemented with $10 \%$ fetal bovine serum and $1 \%(\mathrm{v} / \mathrm{v})$ penicillin-streptomycin in a humidified atmosphere with $5 \% \mathrm{CO}_{2}$ at $37^{\circ} \mathrm{C}$. Dox $(1.2 \mu \mathrm{M}$ or $1.0 \mu \mathrm{M})$ was added to the medium to keep the multidrug-resistant property of HepG2/ADM or MCF7/ADR cells, respectively.

Cytotoxicity assay. The cytotoxicities of compounds 1-8 were determined by MTT assay as previously described. ${ }^{6}$ Briefly, cells $\left(5 \times 10^{3}\right.$ per well) were treated with different concentrations of compounds for $72 \mathrm{~h}$. Then, $5 \mathrm{mg} \mathrm{mL} \mathrm{mTT}^{-1}$ solution was added to each well after removing the medium and further incubated at $37^{\circ} \mathrm{C}$ for $4 \mathrm{~h}$. After that, the formazan crystals were dissolved in $100 \mu \mathrm{L}$ DMSO, and absorbance was measured at $570 \mathrm{~nm}$ by a microplate reader (Thermo Multiskan MK3, Waltham, MA, USA). Cells treated with medium (0.2\% DMSO) was used as negative control. The concentration required to inhibit $50 \%$ cell growth $\left(\mathrm{IC}_{50}\right)$ was calculated from survival curves.

Cell cycle analysis. Cell cycle analysis was performed using a fluorescent probe PIas previously described. ${ }^{15}$ HepG2/ADM cells $\left(3 \times 10^{5}\right.$ per well $)$ were cultured in the presence of compound $8(8.5 \mu \mathrm{M}, 9.0 \mu \mathrm{M}$ or $9.5 \mu \mathrm{M})$ for $72 \mathrm{~h}$, followed by staining with $10 \mu \mathrm{L} \mathrm{PI}\left(0.2 \mathrm{mg} \mathrm{mL}^{-1}\right)$ and $50 \mu \mathrm{L}$ RNase A $(1 \mathrm{mg}$ $\left.\mathrm{mL}^{-1}\right)$ in $500 \mu \mathrm{L}$ PBS in the dark at $37{ }^{\circ} \mathrm{C}$ for $30 \mathrm{~min}$, and examined by Epics XL flow cytometry (Beckman Coulter, Brea, CA, USA). DNA content in different phases of cell cycle was analyzed quantitatively using the Win MDI 2.8 software (The Scripps Institute, La Jolla, CA, USA).

Apoptosis analysis. Apoptosis analysis was measured using an Annexin V-FITC/PI double staining assay kit according to the manufacturer's protocol. HepG2/ADM cells $\left(3 \times 10^{5}\right.$ per well $)$ were treated with compound $8(8.5 \mu \mathrm{M}, 9.0 \mu \mathrm{M}$ and $9.5 \mu \mathrm{M})$ for $72 \mathrm{~h}$. After that, cells were incubated with Annexin V-FITC and PI solution $(1: 1)$ and tested by Epics XL flow cytometry (Beckman Coulter, Brea, CA, USA). Data were analyzed quantitatively with an EXPO32 ADC software (Beckman Coulter, Brea, CA, USA).

Western blot. Cleavage of PARP was evaluated by Western blot. HepG2/ADM cells $\left(2 \times 10^{6}\right.$ per dish $)$ were cultured in the presence of compound $8(8.5 \mu \mathrm{M}$ and $9.5 \mu \mathrm{M})$ for $72 \mathrm{~h}$. Cells were collected and then incubated with RIPA buffer
(20× phosphatase inhibitor, 0.5 M DTT and 0.1 M PMSF) on ice for $10 \mathrm{~min}$. After centrifugation at $13200 \times \mathrm{g}$ at $4{ }^{\circ} \mathrm{C}$ for $15 \mathrm{~min}$, the supernatant was gathered as total protein lysates and stored at $-80{ }^{\circ} \mathrm{C}$ until use. Protein concentration was tested by the BCA protein assay kit. Electrophoresis and immunoblotting analysis was carried out as previously described. ${ }^{6}$

\section{Conclusions}

In this work, six new oleanane-type triterpene saponins and two known compounds were isolated from the aerial parts of Androsace umbellata. The structures were determined on the basis of spectroscopic data and acid hydrolysis. All new compounds showed no obvious cytotoxicity against the test cells. However, cytotoxicity assays indicated that 7 and 8, both bearing a 13ß,28-epoxy group, were active. Compound 8 was shown to induce apoptosis in the HepG2/ADM cells. These results provide a basis for evaluating the structure-activity relationships of other oleanane-type triterpene saponins, as well as for developing the compound $\mathbf{8}$ as potential antihepatoma drug.

\section{Acknowledgements}

The authors thank Prof. Min-Jian Qin (China Pharmaceutical University) for authenticating the plant material and Prof. WenBin Shen (China Pharmaceutical University) for NMR measurements. This work was partially supported by the National Natural Science Foundation of China (No. 81001379), and sponsored by the Ninth Batch of "Six Talent Peaks" Project of Jiangsu Province (No. 2012-YY-008), and A Project Funded by the Priority Academic Program Development of Jiangsu Higher Education Institutions.

\section{Notes and references}

1 J. Y. Wang, X. J. Li, G. Hao and J. Q. Liu, Acta Phytotaxon. Sin., 2014, 42, 481-499.

2 R. X. He, G. F. Wei, H. Yao, Y. Chang, L. Xu and C. L. Zhang, Chin. J. Exp. Tradit. Med. Formulae, 2012, 18, 296-299.

3 J. Lei, Y. C. Xiao, J. Huang, M. Tang and P. C. Deng, Helv. Chim. Acta, 2009, 92, 1439-1444.

4 L. R. Song, Chinese Bencao, Shaihai Science and Technology Press, Shanghai, 1998, vol. 6, pp. 87-89.

5 J. H. Park, J. H. Kwak, J. H. Khoo, S. H. Park, D. U. Kim, D. M. Ha, S. U. Choi, S. C. Kang and O. P. Zee, Arch. Pharmacal Res., 2010, 33, 1175-1180.

6 J. M. Shi, L. L. Bai, D. M. Zhang, A. Yiu, Z. Q. Yin, W. L. Han, J. S. Liu, Y. Li, D. Y. Fu and W. C. Ye, Biochem. Pharmacol., 2013, 85, 913-926.

7 Z. Q. Yin, C. H. Li, Y. Wang, W. C. Ye and J. Zhang, Chin. Chem. Lett., 2009, 20, 836-838.

8 Y. Wang, D. M. Zhang, W. C. Ye, Z. Q. Yin, K. P. Fung, S. X. Zhao and X. S. Yao, Planta Med., 2008, 74, 1280-1284.

9 J. P. Waltho, D. H. Williams and S. B. Mahato, J. Chem. Soc., Perkin Trans. 1, 1986, 1527-1531. 
10 N. Andre, D. W. Anthony, S. Otto and R. Topul, J. Nat. Prod., 1994, 57, 1245-1250.

11 K. Koike, Z. H. Jia, S. Ohura and S. Mochida, Chem. Pharm. Bull., 1999, 47, 434-435.

12 A. Yokosuka, T. Sano, K. Hashimoto, H. Sakagami and Y. Mimaki, Chem. Pharm. Bull., 2009, 57, 1425-1430.

13 Y. Shao, B. N. Zhou and J. H. Gao, Phytochemistry, 1995, 38, 675-680.
14 D. M. Zhang, J. S. Liu, M. K. Tang, A. Yiu, H. H. Cao, L. Jiang, J. Y. Chan, H. Y. Tian, K. P. Fung and W. C. Ye, Eur. J. Pharmacol., 2012, 692, 19-28.

15 J. S. Liu, D. M. Zhang, Y. Li, W. M Chen, Z. X. Ruan, L. J. Deng, L. W. Wang, H. Y. Tian, A. Yiu, C. L. Fan, H. Luo, S. W. Liu, Y. Wang, G. K. Xiao, L. X. Chen and W. C. Ye, J. Med. Chem., 2013, 56, 5734-5743. 